\title{
What Reason for the Quest?: A Response to Professor Scott*
}

\author{
C. Westbrook Murphy†
}

\section{INTRODUCTION}

Professor Kenneth E. Scott was from 1963 to 1967 the General Counsel of the Federal Home Loan Bank Board. Since then he has kept abreast of administrative law developments involving the licensing decisions of the federal banking agencies. His collection of written opinions by the Comptroller of the Currency approving branch banks may be the only complete set outside the Comptroller's Office. More recently, Professor Scott was given access to a random sample of cases from the internal files of the Comptroller's Office. In view of this extensive background, it is disappointing to find that his article on the decision-making process in bank regulation ${ }^{1}$ amounts to not much more than a warmed over-although more entertainingly written-version of ideas expressed in dozens of briefs filed with courts in the last ten years by plaintiffs seeking unsuccessfully to overturn decisions of the banking agencies.

Professor Scott starts with some erroneous assumptions about the statutory discretion vested in the Comptroller; continues by resurrecting issues about hearing procedures and the scope of judicial review that were settled by the federal courts six or seven years ago; ${ }^{2}$ throws in a plug for the issuance of bank charters to

* The views expressed herein are those of the author only, and do not necessarily represent the views of the Comptroller's Office. Professor Scott originally prepared his article for consideration by the Administrative Conference of the United States, as a consultant to that Conference. The Comptroller's official response has been sent to the Administrative Conference.

$\dagger$ Deputy Chief Counsel, Office of the Comptroller of the Currency.

1. Scott, In Quest of Reason: The Licensing Decisions of the Federal Banking Agencies, 42 U. Chi. L. Rev. 235 (1975) [hereinafter cited as Scott].

2. The Supreme Court decision in Camp v. Pitts, 411 U.S. 138 (1973), was not as unexpected as the Scott article might lead one to believe. On the contrary, the Court's decision confirmed results already reached by the Third, Fourth, Fifth, Sixth, Eighth, and District of Columbia Circuit Courts of Appeals. The Ramapo Bank v. Camp, 425 F.2d 333 (3d Cir.), cert. denied, 400 U.S. 828 (1970); First-Citizens Bank \& Trust Co. v. Camp, 409 F.2d 1086 (4th Cir. 1969); Citizens Bank of Hattiesburg v. Camp, 387 F.2d 375 (5th Cir. 1967), cert. denied, 391 U.S. 904 (1968); Sterling Nat'l Bank of Davie v. Camp, 431 F. 2d 514 (5th Cir. 
anyone over eighteen who can sign his name, hire a lawyer to fill out the forms, and persuade enough people to invest the necessary capital; and concludes that the federal banking agencies should publish chartering standards, or issue written opinions in every case, or both. Because of its abundance of irrelevant arguments and its paucity of discussion about the real issues raised by its conclusions and recommendations, the article is not of much use in determining whether or not published standards and written decisions have any valid place in modern banking supervision.

This response will attempt to correct some of the misconceptions in the Scott article. It will examine critically Professor Scott's assertions that the facilitation of judicial review and the need for good administration require written explanations of banking agency decisions. An issue not treated by Professor Scott, the possible need for confidentiality in some banking agency decisions, will be explored briefly. Finally, this response will suggest that there is a tension between facilitating judicial review and encouraging meaningful discussions of economic and banking issues. In discussing these questions I will focus principally upon the Office of the Comptroller of the Currency, both because of my familiarity with the Comptroller's Office and because of the similar focus in Professor Scott's article.

\section{Existing Standards and Procedures}

\section{Charters}

We might begin by noting that the Comptroller has published regulations concerning the discretionary matters that he investigates in considering new charters. These factors include:

(1) The adequacy of the proposed bank's capital structure.

(2) The earning prospects of the proposed bank.

(3) The convenience and needs of the community to be served by the proposed bank.

(4) The character and general standing in the community or [sic] the applicants, prospective directors, proposed officers,

1970), cert. denied, 401 U.S. 925 (1971); Warren Bank v. Camp, 396 F.2d 52 (6th Cir. 1968); Webster Groves Trust Co. v. Saxon, 370 F.2d 381 (8th Cir. 1966); First Nat'l Bank of Fairbanks v. Camp, 465 F.2d 586 (D.C. Cir. 1972), cert. denied, 409 U.S. 1124 (1973). None of these cases was cited, discussed, or distinguished by Judge Bryant in his opinion for the court of appeals in Pitts v. Camp, 463 F.2d 632 (4th Cir. 1972). The only banking case cited by Judge Bryant was his own earlier opinion in First Nat'l Bank of Smithfield v. Saxon, 352 F.2d 267 (4th Cir. 1965). 
and other employees, and other persons connected with the application or to be connected with the proposed bank.

(5) The banking ability and experience of proposed officers and other employees. ${ }^{3}$

This published regulation, together with the questions asked in the summary of information that each charter applicant must submit to the Regional Comptroller, ${ }^{4}$ outlines the factors considered by the Comptroller in passing upon charter applications.

These discretionary considerations are derived from sections 17 and 18 of the National Bank Act. ${ }^{5}$ Those provisions require the Comptroller to examine into the condition of any proposed national banking association and to ascertain, among other things, "generally whether such association has complied with all the requirements of this chapter to entitle it to engage in the business of banking . ..." The Comptroller is to examine the information reported by the organizers of the proposed bank and "any other facts which may come to the knowledge of the comptroller, whether by means of a special commission appointed by him for the purpose of inquiring into the condition of such association, or otherwise ...." If upon this examination it appears that "such association is lawfully entitled to commence the business of banking, the comptroller shall give to such association a certificate .. . that such association is authorized to commence" the business of banking. ${ }^{8}$

A historical examination of this 1864 statute shows that itand not the Federal Deposit Insurance Act (FDI Act), ${ }^{9}$ as asserted by Professor Scott-is the basis of the Comptroller's chartering discretion. The National Bank Act $^{10}$ was a substantial revision and reenactment of the National Currency Act of $1863,{ }^{11}$ which had created both the national banking system and the Office of the Comptroller of the Currency. The first Comptroller of the Currency, Hugh McCulloch, and the then Secretary of the Treasury, Salmon P. Chase, were the principal authors of the 1864

3. 12 C.F.R. $\S 4.2$ (b) (1974).

4. This form is reprinted as the Appendix to the Scott article. Scott 297-98.

5. Act of June 3,1864 , ch. 106, $\S \S 17-18,13$ Stat. 104, as amended, 12 U.S.C. $\S \S 26-27$ (1970).

6. 12 U.S.C. $\S 26(1970)$.

7. Id. $\$ 27$.

8. Id.

9. Act of Sept. 20, 1950, ch. 967, 64 Stat. 873, as amended, 12 U.S.C. $\$ \$ 1811-31$ (1970).

10. Act of June 3, 1864, ch. 106, 13 Stat. 99.

11. Act of Feb. 25, 1863, ch. 58, 12 Stat. 665. 
Act. ${ }^{12}$ This historical background makes especially important Comptroller McCulloch's views of the intent of the chartering provisions of the 1864 Act. ${ }^{13}$

In January of 1865 Comptroller McCulloch responded to an inquiry as follows:

Before sending out Forms, for the organization of a $\mathrm{Na}$ tional Bank, it is desired that I should be informed as to the following points-

lst, the place where they are to be used, its business, population, etc., etc.

2nd, the parties to the proposed organization.

3rd, what banking facilities exist in the vicinity.

For this reason I have desired all the parties asking for Forms to address a letter to this office on these subjects.

Other notations on various pieces of incoming correspondence during 1864 and 1865 give a good picture of Comptroller McCulloch's views: "Ask for information as to business and population." "Must include best and most responsible businessmen." "Don't want individual Bank or close corporation." "Can't encourage. One bank there now. Another not profitable to stockholders or credit to system." 14 Thus there seems to have been little question in the mind of the statutory draftsman that discretion was conferred by the language of sections 17 and $18 . .^{15}$

12. In the early 1960s the Comptroller's Office discovered a notebook containing a pasteup of the 1863 Act with the revisions written in by Comptroller McCulloch and Secretary Chase. This notebook is now with the National Archives.

13. The weight given to contemporaneous administrative construction of federal statutes is stressed in Udall v. Tallman, 380 U.S. 1, 16 (1965), and other cases.

14. This and other similar correspondence was a part of the court record in two of the cases referred to by Professor Scott. Pitts v. Camp, 329 F. Supp. 1302 (D.S.C.), vacated, 463 F.2d 632, vacated, 411 U.S. 138 (1971); Olsen v. Camp, 328 F. Supp. 728 (E.D. Mich. 1970).

15. 12 U.S.C. $\S \S 26 \& 27$ (1970).

One of Comptroller McCulloch's notations pinpoints one of the reasons the Comptroller was given broad discretion in the bank chartering field. When asked in January of 1865 if it was true that his department would receive no more applications for national banks in Philadelphia, Comptroller McCulloch replied:

I am of the opinion that the Comptroller of the Currency should exercise proper discretion in the location of Banking under the National Currency Act having reference to the distribution of the circulation provided for by that act, so that there may not be an undue amount in one locality to the exclusion of others.

I am also of opinion that the seaboard cities already have their due proportion or more than that of Banking Capital.

In 1865, of course, the number and location of national banks could have a direct impact on the money supply, because national banks were authorized to issue bank notes, the circulating medium for the country. Today, in a similar if less obvious way, the Comptroller's decisions on charters and branches have an impact upon the money supply (over ninety percent of which is demand deposits in commercial banks), the availability of credit, and the 
Similar statements can be found in annual reports of the Comptroller up to the present day. Contrary to the impression left by Professor Scott, the notion that the Comptroller lacks discretion to consider economic, management, or other discretionary factors in the chartering process has been held only for a brief period by a few Comptrollers. History would suggest that the Comptrollers who viewed their chartering role as ministerial rather than discretionary were reacting more to the economic climate of the times, and to a desire to keep pace in a chartering race with state authorities, than to any close analysis of the language of the National Bank Act.

Professor Scott therefore errs in stating ${ }^{16}$ that the Comptroller's authority to exercise discretion stems from sections 4 and 6 of the FDI Act. ${ }^{17}$ Section 4 requires the Comptroller to certify to the Federal Deposit Insurance Corporation "that consideration has been given to" factors enumerated in section 6 of the Act. These statutory factors ${ }^{18}$ are similar to those enumerated in the Comptroller's regulation quoted above; but the latter are not dependent upon the former. The Comptroller's regulation would stand on the solid base of the National Bank Act even if there were no federal deposit insurance system. The Comptroller, moreover, is required to certify only that "consideration has been given" to the factors; he is not required to certify what investigation he conducted or what conclusion he reached.

The invariable procedure in approving an application to organize a new national bank is to grant preliminary approval based upon evaluation of the banking, economic, and managerial factors, with final chartering contingent upon completion of such important steps as selling capital stock, securing a bank building, and hiring officers and employees satisfactory to the Comptroller's Office. It is not until all these steps have been completed and the bank is ready to open that the Comptroller certifies to the FDIC that consideration has been given to the factors enumerated in section 6 of the FDI Act. The preliminary approval, however, is

effectiveness of the Federal Reserve System (national banks own seventy-five percent of the assets held by Federal Reserve System member banks).

16. Scott 240 .

17. 12 U.S.C. $\S \S 1814 \& 1816$ (1970).

18. The factors enumerated in section 6 are:

The financial history and condition of the bank, the adequacy of its capital structure, its future earnings prospects, the general character of its management, the convenience and needs of the community to be served by the bank, and whether or not its corporate powers are consistent with the purposes of this [act].

12 U.S.C. § 1816 (1970). 
considered to be the final action of the Comptroller for purposes of judicial review, ${ }^{19}$ and all the cases challenging the Comptroller's approval of a national bank charter have been filed, and in some instances even decided, before the Comptroller has made the required certification. When an application is disapproved, the Comptroller neither takes any action under, nor makes any reference to, the FDI Act.

\section{Branches}

Although the Comptroller has no published regulations concerning his inquiries into branch applications, he has indicated ${ }^{20}$ that he investigates policy factors almost identical to those contained in his regulation governing charter applications. As Professor Scott mentioned, branch applicants submit a summary of information similar to that supplied by new bank organizers. Moreover, the factual part of the investigating examiner's report is available to the public. Although these sources may not be familiar to Professor Scott's audience, they are generally known in the banking industry and give a comprehensive outline of the factors considered by the Comptroller.

The statute concerning branch banks provides, in language which originated with the McFadden Act of $1927,{ }^{21}$ that national banks may establish and operate branches as provided in that statute "with the approval of the Comptroller of the Currency."22 As the court stated in Apfel $v$. Mellon, ${ }^{23}$ "an examination of congressional legislation with regard to banking since 1864 shows that Congress has consistently used various forms of the word 'approve' in the sense of conferring discretion upon the Comptroller of the Currency, the Secretary of the Treasury, or the Federal Reserve Board."24 The branch bank statute thus gives the Comptroller discretion to determine what factors he will consider in granting or denying an application.

\section{Professor Scott's Arguments}

Having clearly established the statutory basis for the Comptroller's exercise of discretion in passing upon applications

19. First Nat'l Bank of Fayetteville v. Smith, 508 F.2d 1371 (8th Cir. 1974), petition for cert. filed, 43 U.S.L.W. 3439 (U.S. Feb. 4, 1975) (No. 963).

20. Office of the Comptroller of the Currency, Comptroller's Policy Guidelines for National Bank Directors 43-45 (1964).

21. Act of Feb. 25, 1927, ch. 191, § 7, 44 Stat. 1228.

22. 12 U.S.C. $\$ 36(c)(1970)$.

23. 33 F.2d 805 (D.C. Cir.), cert. denied, 280 U.S. 585 (1929).

24. Id. at 807 . 
for charters and branch banks, we now are in a position to examine Professor Scott's suggestion that the Comptroller's Office should publish predictive standards and case by case opinions in order both to facilitate judicial review and to improve administration of an important governmental function.

\section{Facilitating Judicial Review}

Of the two reasons, the facilitation of judicial review appears to be the less plausible. Professor Scott himself seems contradictory on this point. In one place he appears to favor "standards or findings by which [the courts could] examine a record for substantial supporting evidence." 25 At the same time, he recognizes that "[j]udicialization of agency decision making is a remedy often prescribed, but its cost in terms of delay and expense frequently exceed by a wide margin its contribution toward improving the quality of decisions." ${ }^{26}$ Written standards and opinions, used by the courts in individual cases as touchstones for a substantial evidence determination, ${ }^{27}$ inevitably change the character of judicial review and judicialize the underlying administrative proceedings.

Lawyers and judges are rarely experts on banking, but they do know something about semantic hairsplitting. Judicial review of a written agency opinion focuses not on whether the administrative decision is good policy, but on whether or not the opinion is well written-that is, written as a lawyer would write it. In government economic regulatory agencies that are required by statute to write

25. Scott 257.

26. Id. at 290 (footnote omitted).

27. There is, of course, no statute requiring the Comptroller to hold formal administrative proceedings or to base his decision upon a formal administrative record. Neither does any statute define the scope of judicial review. In this situation, "the proper standard for judicial review of the Comptroller's adjudications is not the 'substantial evidence' test which is appropriate when reviewing findings made on a hearing record, 5 U.S.C. $\$ 706$ (2)(E)." Camp v. Pitts, 411 U.S. 138, 141 (1973). The appropriate standard of review is "whether the Comptroller's [decision is] 'arbitrary, capricious, an abuse of discretion, or otherwise not in accordance with law." "Id. at 142, citing 5 U.S.C. \& 706(2)(A) (1970). The difference between these two standards was discussed recently by the Eighth Circuit:

The "arbitrary and capricious" standard of review is a narrow one. Citizens to Preserve Overton Park, Inc. v. Volpe, [401 U.S. 402, 416 (1971)]. Its scope is more restrictive than the "substantial evidence" test which is applied when reviewing formal findings made on a hearing record. See Camp v. Pitts ... ; Webster Grotes Trust Co. v. Saxon, supra, 370 F.2d at 387; Charlton \%. United States, 412 F.2d 390, 398 (3d Cir. 1969) (Stahl, Circuit Judge, concurring). "Administrative action may be regarded as arbitrary and capricious only where it is not supportable on any rational basis." Carlisle Paper Box Co. v. N.L.R.B., 398 F.2d 1, 6 (3d Cir. 1968). Something more than mere error is necessary to meet the test.

N.L.R.B. \%. Parkhurst Manufacturing Co., 317 F.2d 513, 518 (8th Cir. 1963).

First Nat'l Bank of Fayetteville v. Smith, 508 F.2d 1371, 1374 (8th Cir. 1974), petition for cert. filed, 43 U.S.L.W. 3439 (U.S. Feb. 4, 1975) (No. 963). 
opinions or make findings based upon an administrative record, issues frequently are resolved on the basis of whatever factors seem relevant to the agency head, whether a single individual or a commission. The case is then turned over to a staff member to write an opinion that would be acceptable to a reviewing court. The staff member is more concerned with avoiding reversal on appeal than with explaining the real reason for the decision-assuming he knows what the reason is. He thus checks all page references carefully, discusses a check list of statutory considerations, and mentions all of the factors the court enumerated in the last case involving his agency, whether or not those factors are important to the decision at hand. He calculates that, since courts are creatures guided by precedent, new arguments should be avoided-they may be unacceptable to a court simply because they didn't appear in the previous cases. The result is an acceptable collection of words whose relation to the real issues may be only coincidental.

This is a process which delays agency decisions for several months (so that it is of dubious value in terms of improving agency performance) and which, when combined with more and more judicial review, feeds upon itself, turning the decision-making process more and more into a lawyers' game. Professor Scott nonetheless asserts that the staff of the banking agencies should be increased precisely for this purpose. As suggested in the portion of Professor Davis's treatise quoted in the Scott article, however, a comparison of this formal decision-making process with the more informal approach of the banking agencies "might well prove that the nonbanking agencies have a good deal to learn from the banking agencies."28

Considerations of Good Administration

Professor Scott states his real reason for published predictive standards and/or written opinions as follows:

But however full or inadequate the explanation that the courts are prepared to demand, the requirements of good administration are an independent matter. Banking plays too central a role in our economic system, and the issues at stake in the administration of entry controls are too important, for a continuation of the present regime of unexamined and unexplained exercises of discretion. Whether they are ultimately forced to it by the courts or not, the banking agencies should

28. 1 K. Davis, Administrative Law Treatise $\S 4.04$ (1958). 
articulate their policies and their reasons-and not in the curt and superficial manner in Pitts. $^{29}$

But this principle is not self-enacting. If the Comptroller could write standards sufficiently detailed to cover every foreseeable situation, the bank chartering process could be handled by a file clerk, who would simply compare each application to the check list in the Comptroller's standards to determine whether the charter should be granted. Indeed, applicants themselves probably would refrain from submitting applications that failed to meet the published standards, and thus the Comptroller would receive only applications that should be approved. If predictable and consistent results are a desirable goal, this situation sounds like nirvana. Professor Scott's article offers little help, however, on the difficult problem of writing such standards.

Although Professor Scott never directly discusses the Comptroller's published chartering standards, he seems to find the similar standards in the Federal Deposit Insurance Act to be too vague. $^{30} \mathrm{He}$ also finds unenlightening general statements of philosophy appearing in public speeches and annual reports. ${ }^{31}$ On the other hand, he notes, ${ }^{32}$ in connection with his discussion of Bank of Haw River $v$. Saxon, ${ }^{33}$ that rigid application of a bankingoffice-to-population ratio produces arbitrary results. Professor Sccott thus tells us to stay away from Charybdis because it is too frothy and to avoid Scylla because it is too hard. He tells us that a course exists between these two alternatives, but he gives little guidance on how to find it. ${ }^{34}$

Recommendation 2 of the Scott article carries the seed of a constructive idea when it states:

For branches, therefore, the Comptroller and the FHLBB should furnish written opinions only when so requested by the applicant or by objectors, or when the agency believes the case presents issues of general importance. It would be appropriate to charge the requesting party an amount commensurate with the time cost of opinion preparation. ${ }^{35}$

29. Scott 293 (footnote omitted).

30. Id. at 242.

31. Id. at 243.

32. Id. at $250-51$.

33. 257 F. Supp. 74 (M.D.N.C. 1966).

34. Cf. Scott 294 (Recommendation 1).

35. Id. at 294-95 (footnote omitted). 
There are drawbacks to the notion of issuing opinions in response to any request accompanied by cash on the barrelhead. ${ }^{36}$ The Comptroller's Office, however, already writes opinions when it concludes that the case is of general importance, or that an expression of the Comptroller's reasoning might aid a reviewing court. ${ }^{37}$ The number of such cases is small enough that the Comptroller can participate personally in a meaningful way in the opinion writing; thus both the staff and the public are sure that the opinion reflects his views. Indeed, I recall at least one instance in which the staff wrote two opinions, one approving and one denying an application, and the Comptroller read both, decided the issue, and himself wrote the final opinion. This is a decision process that can highlight the issues in difficult and unusual cases, although it hardly can be employed each of the thousand or so times a year that the Comptroller determines-whether a new banking office is useful or needed on a particular street corner. The resulting decision also satisfies Professor Scott's goal of informing the public why the Comptroller acted as he did.

At the theoretical level, it is difficult to argue that the government-including a lot more of it than just the banking agencies-should not be forced to spell out in writing for guidance of the citizenry exactly what its reaction would be to a given set of circumstances. The absence of such guidelines may have caused many of us, for example, to experience a brief, agonizing period of uncertainty wondering what the reaction would be of the traffic cop who has just discovered us driving three miles per hour faster than the speed limit. In the real world, however, government agencies-like other institutions and individuals - do not have time to write standards concerning the many sorts of circumstances that might or might not arise. Even if the time were available, the standards produced would likely be of low quality and of little value. Those of us who are not professors and are faced with a myriad of concrete problems find it difficult to concentrate upon and give our best efforts to the writing of abstract predictive standards. And even with all the time and attention in the world, it is impossible to design a scheme that will cover every foreseeable situation-which is probably the reason that Professor Scott's article offers very little

36. As a practical matter, protestants probably always would request an opinion just to obtain the delay involved. Additionally, if these opinions provide the great public benefit imagined by Professor Scott, it hardly seems fair to charge a private party for it.

37. See, e.g., Seattle Trust \& Sav. Bank v. Bank of Cal., 492 F.2d 48 (9th Cir. 1974), which reviewed a decision of the Comptroller, supported by a written opinion, authorizing the Bank of California, N.A., San Francisco, to establish and operate a branch in Seattle. 
guidance about what his proposed regulation would look like. Simply from lack of foresight, any predictive standards probably would not cover the difficult and unusual cases-the very ones on which guidance would be most useful. I thus hesitate to embrace Professor Scott's suggestion that the banking agencies develop published criteria until I know more than the Scott article tells me about some of the practical problems involved.

\section{The Need for Confidentiality}

One practical problem that the Scott article fails to explore concerns the way in which a published decision sometimes affects the solvency of a particular bank. An unfavorable opinion from a banking agency can shatter public confidence in a banking institution. This problem is illustrated by the factual background surrounding Olsen $v$. Camp $p^{38}$ - a case discussed by Professor Scott. In that case organizers of a proposed new bank sought judicial review of the Comptroller's denial of a charter application. As Professor Scott notes, executive privilege was claimed-ultimately by the Secretary of the Treasury-for a portion of the file relating to the unsatisfactory condition of other banks with which some of the applicants were then associated. ${ }^{39}$ Because of possible consequences for these banks, the Comptroller refused to produce in court these portions of the file, and litigated for more than two years various discovery questions relating to these documents.

Meanwhile, Bank of the Commonwealth, a billion-plus dollar bank located in Detroit and the lead bank in the group of banks in question, filed two applications with the Board of Governors of the Federal Reserve System. One application was to establish an overseas branch in Nassau; the other was to charter a foreign banking corporation under the provisions of the Edge Act. ${ }^{40}$ The Board of Governors denied the applications in separate, simultaneous written opinions on the ground that "the general character of Bank of the Commonwealth management and the bank's financial history and condition, including its liquidity and capital positions, militate against approval." The publication of these decisions began a disastrous year for Bank of the Commonwealth and several other banks associated with it. Bank of the Commonwealth was saved from insolvency by a $\$ 35$ million loan from the FDIC. Birmingham-

38. 328 F. Supp. 728 (E.D. Mich. 1970).

39. Id. at 730-31.

40. Act of Dec. 24, 1919, ch. 18, 41 Stat. 378, codified at 12 U.S.C. $\$ \$ 611$ et seq. (1970). 
Bloomfield Bank, a $\$ 60$ million institution located in Birmingham, Michigan, was declared insolvent-although the FDIC was able to give financial assistance in a transaction by which a newly chartered state bank assumed all of Birmingham-Bloomfield's deposit liabilities, thus preventing any loss to depositors. Other banks in the group experienced serious, but less severe, problems.

Although publication of the opinion by the Federal Reserve Board apparently solved some supervisory problems that had been facing the banking agencies, ${ }^{41}$ and although the result for the shareholders and management of these banks might be called "just," a substantial risk was created for the banks' depositors. The Olsen case thus illustrates that the underlying philosophy of bank regulation-protection of depositors-does not always mesh well with a system of public disclosure of facts whose publication could result in the bank's insolvency. Should the Comptroller be required publicly to assert that a bank management is incompetent whenever he denies a branch bank application on that ground? ${ }^{42}$ The question could sustain a lively debate on the philosophy of bank regulation, but the issues involved are barely touched in the Scott article, ${ }^{43}$ much less explored in any meaningful way. Such an exploration is necessary to any intelligent consideration of Professor Scott's four recommendations.

\section{The Tension Between Judicial Review and Meaningful Policy Statements}

Professor Scott, after discussing the cases, concludes that "judicial review of the Comptroller's decisions that is both limited and intelligent seems to be . . . as far away as ever." $44 \mathrm{He}$ also notes that policy statements and rulemaking are preferable to opinions in individual cases, but that " $[t]$ here is little that courts can do to force an agency to use its rulemaking authority . . .." Finally he contends that "the requirements of good administration are an

41. Publication of the opinion also resulted in voluntary dismissal of the Olsen case without the contested documents ever having been produced.

42. The bank itself would be told the reason for the denial because the Comptroller's Office would use the denial to encourage the applicant to run a better bank.

43. At one point, Scott 294 , the article suggests that public confidence in a bank in financial difficulty would be "unwarranted." Stating that a situation is "unwarranted" does not remove the difficult problem of finding an acceptable way to accomplish improvements.

44. Scott 268 .

45. Id. at 291 (footnote omitted). 
independent matter," and that "[w]hether they are ultimately forced to it by the courts or not, the banking agencies should articulate their policies and their reasons ...."46

Professor Scott fails to draw what may be the obvious conclusion from this reasoning: that courts are not and cannot be very effective in promoting the articulation of economic and banking policies; therefore, that goal might be achieved better by curtailing or eliminating judicial review of licensing decisions rather than by increasing it. It already has been suggested that there is limited value in altering administrative procedures solely to facilitate judicial review. What now is suggested is the converse: perhaps the nature of judicial review should be changed to facilitate the administrative process.

As already noted, judicial review does not encourage an agency to engage-through rulemaking, decisions, or otherwise-in the debates necessary to articulate economic and banking standards of the kind sought by Professor Scott. Instead, lawyers and judges, with their penchant for precedents, tend to look for and question any variation between the administrative decision under review, on the one hand, and prior agency or court cases on the other. This practice encourages administrative agencies to recite rote formulas rather than to undertake thoughtful analysis of subtle economic and public policy issues. Thus, if candid, forthright statements of policy are preferred, we should consider discouraging, rather than encouraging, judicial review.

Judging by the record of the last ten years, if judicial review of the Comptroller's licensing decisions were eliminated altogether nobody would miss it but lawyers. The Comptroller has never lost a case challenging his grant or denial of a charter. In the branching area, the losses have averaged fewer than one out of the several dozen cases decided each year-and few of those losses have been of any significance. The impact of judicial review upon the agency decision-making process, therefore, has not been significant.

The principal result of judicial review of the Comptroller's decisions has been to subject successful applicants to unwarranted and expensive delays. Unfounded preliminary injunctions were becoming so common in North Carolina that the Comptroller had to appeal one of them in an effort to discourage litigants from bringing suits for the sole purpose of delay. ${ }^{47}$ In the District of Columbia, the district court's preliminary injunction in Wood County Bank

46. Id. at 293 (footnote omitted).

47. The case appealed was First-Citizens Bank \& Trust Co. v. Camp, 42 F.2d 481 (4th 
v. Camp, ${ }^{48}$ which it issued without requiring any kind of bond, was met with a shrug by the court of appeals; ${ }^{49}$ indeed, in First National Bank of Fairbanks v. Camp, ${ }^{50}$ the court of appeals itself had issued, ex parte and without any bond, an order closing down the branch involved for more than a year, despite a summary judgment for the Comptroller granted by the district court. Recently, the Tenth Circuit-on its own motion, without soliciting the views of the parties, without requiring any bond, and without referring to the considerations usually involved in staying administrative decisions ${ }^{51}$ - enjoined, pending further proceedings, the imminent opening of a new bank that had sold its shares, built its building, and hired its officers and employees. ${ }^{52}$ If Professor Scott were to examine these cases, he might have more faith in the banking agencies and less in reviewing courts.

Elimination of judicial review in the licensing area would not leave the Comptroller free of all economic and banking standards and all principles of fairness. First, as Professor Scott points out in his advocacy of free banking, ${ }^{53}$ even when the Comptroller's approval is obtained the public still determines whether there is a need for a particular banking office. I once heard a judge suggest from the bench that if the plaintiff bank would serve its customers better it would not need to worry about the new competition it was seeking to prevent. I often wonder why more courts have not reacted similarly. Second, my suggestion of a cutback in judicial review assumes an expansion in the Comptroller's administrative expression of his licensing policies; so accountability can be had through the political process and in the philosophical market place of ideas. The district court in Warren Bank v. Saxon ${ }^{54}$ explained this idea as follows:

Cir. 1970). Plaintiffs' lawyers sometimes have told me point blank that they have brought cases or considered bringing cases solely for the delay involved.

48. 348 F. Supp. 1321 (D.D.C.), vacated, 489 F.2d 1273 (D.C. Cir. 1972).

49. The appellate court action referred to in the text was an unreported denial of a motion for summary reversal of the district court's injunction. But FED. R. Civ. P. 65(c) appears to require a bond before issuance of a preliminary injunction. This should be compared with the discretionary language in FED. R. APP. P. 8(b).

50. 465 F.2d 586 (D.C. Cir. 1972), cert. denied, 409 U.S. 1124 (1973), aff'g 326 F. Supp. 541 (D.D.C. 1971).

51. See, e.g., Virginia Petroleum Jobbers Ass'n v. FPC, 259 F.2d 921, 925 (D.C. Cir. 1958).

52. American Bank of Tulsa v. Smith, 503 F.2d 784 (10th Cir. 1974).

53. Scott 284.

54. Warren Bank v. Saxon, 263 F. Supp. 34 (E.D. Mich.), aff'd, 396 F.2d 52 (6th Cir. 1966). 
We will assume, even, that the Comptroller was "wrong" in his decision. But there is no requirement in the law that he always be "right." His broad discretion includes the discretion to make a mistake. The theory behind the statutory scheme is that with enough mistakes collective action will ultimately come from the citizenry at the polls. Thus reviewability, save in extreme cases, is not entrusted to the courts. ${ }^{55}$

Professor Scott seems to have started with the premise that judicial review is a positive good and, with somewhat less assurance, to have suggested that the process of bank licensing should be altered to increase the availability and effectiveness of judicial review. I suggest, instead, that what Professor Scott really wants is a lively debate on the economic and other standards that should govern bank chartering, with the banking agencies keeping score in the form of published predictive standards. That no such lively debate has been facilitated by judicial review even Professor Scott seems to recognize. That such a debate may be discouraged by judicial review is a possibility which he disappointingly does not discuss.

\section{CoNCLUSION}

It may be that the banking agencies should write more opinions or develop published standards. But Professor Scott does not explain to us very well why this is so and fails even to suggest how the banking agencies might go about it. I hope that the Administrative Conference of the United States will not feel compelled to justify its investment in Professor Scott's article ${ }^{56}$ by adopting his four recommendations-at least not without a good deal more careful study than has so far been undertaken.

55. Id. at 38 .

56. See note * supra. 